\title{
ANALISIS PENGARUH TOTAL ASSET, LABA BERSIH, INFLASI, DAN BI RATE TERHADAP PERGERAKAN HARGA SAHAM: STUDI PADA PERUSAHAAN MANUFAKTUR BEI
}

\author{
Wahyu Ika Kusuma Ningrum \\ David Kaluge \\ Program Magister Ilmu Ekonomi Universitas Brawijaya \\ Email: wahyo3.cutez@gmail.com
}

\begin{abstract}
This study aimed to test whether the effect of Total Assets, Net Income (Net Revenue), Inflation, and the BI Rate to shares in companies isted on the Stock Exchage in 2005-2014. Another purpose of this study was to see if there is a significant influence on the movement of stock prices BEI manufacturing company to Total Assets, Net Income (Net Revenue), Inflation, and the BI Rate. This research sample is manufacturing companies listed on the Stock Exchange in 2005-2014 and selected by random sampling method. Data used is panel data by type of secondary data collected by the method of documentation. Hypothesis testing was conducted using multiple regression analysis as seen from the R-squared with Eviews program. The results of this study indicate that the Total Assets, Net Income (Net Revenue), Inflation, have a significant influence on stocks. While the BI Rate has a significant influence on stock price. This research contributes to the development of capital markets, especially related to stock price.
\end{abstract}

Key words: Total Assets, Net Income (Net Revenue), Inflation, BI Rate dan Stock Price

\section{PENDAHULUAN}

asar Modal adalah salah satu alternatif pilihan investasi yang dapat menghasilkan tingkat keuntungan optimal bagi para investor. Pasar modal memberi peranan penting bagi perusahaan untuk menawarkan dan memperdagangkan saham kepada masyarakat luas. Investor akan memilih perusahaan yang mampu memaksimalkan nilai perusahaan. Untuk itu, setiap investor membutuhkan informasi tentang saham yang akan digunakan dalam menyusun strategi dalam pengambilan keputusan di pasar modal. Pasar Modal selain memberikan keuntungan kepada perusahaan penerbit surat berharga, dapat juga memberikan peluang keuntungan kepada investor. Investor dapat memilih obyek investasi dengan beragam tingkat pengembalian dan tingkat risiko yang dihadapi. Pasar modal di Indonesia

QE Journal | Vol.06 - No. 01 Maret 2017 - 71 
dalam perkembangannya telah menunjukkan tempatnya sebagai bagian dalam instrumen perekonomian, dimana indikasi yang dihasilkannya banyak dipicu oleh para peneliti maupun praktisi dalam melihat gambaran perekonomian Indonesia. Terkait mengenai pasar modal di Indonesia, maka dapat dikatakan bahwa pasar modal di negara Indonesia merupakan pasar yang sedang berkembang dengan pesat. Pertumbuhan dari harga saham yang tercatat di Bursa Efek Indonesia (BEI) yang tercermin dalam pergerakan Indeks Harga Saham Gabungan (IHSG) telah menunjukkan pertumbuhan yang jauh lebih baik dibandingkan regionalnya bahkan jika dibandingkan dengan beberapa negara besar di dunia.

Pergerakan pasar modal menjadi salah satu indikator penting dari pergerakan perekonomian suatu negara, disamping itu juga menjadi salah satu sumber permodalan yang sangat potensial bagi dunia usaha. Dalam pergerakan pasar modal ini, perdagangan saham merupakan salah satu elemen yang terpenting, sehingga memberdayakan masyarakat luas untuk berpartisipasi dalam pergerakan pasar modal khususnya penting untuk digalakkan. Harga saham meningkat berarti pemegang saham menjadi lebih kaya dan mampu memenuhi kebutuhan lebih banyak lagi, yang berarti pemegang saham menjadi lebih makmur (Hermuningsih dan Dewi, 2009). Sehubungan dengan harga saham, nilai perusahaan juga dapat diukur dari return sahamnya. Nilai perusahaan diukur dari return saham karena tujuan investor berinvestasi adalah untuk mendapatkan keuntungan atau pengembalian yang tinggi dengan tingkat risiko tertentu (Suharli, 2005).

Faktor internal dalam mempengaruhi kemampuan perusahaan yang gopublic dalam mencapai tujuan jangka panjangnya untuk meningkatkan nilai perusahaan dapat dilihat dari kinerja keuangannya. Kinerja keuangan perusahaan merupakan salah satu faktor yang dipertimbangkan oleh para investor dalam berinvestasi. Salah satu rasio keuangan yang dapat digunakan sebagai indikator dalam mengukur kinerja keuangan perusahaan adalah rasio profitabilitas. Tidak hanya faktor internal, kondisi ekonomi makro sebagai faktor eksternal juga dapat mempengaruhi kinerja dan nilai perusahaan. Laju inflasi yang tinggi akan mendorong kenaikan harga bahan baku dan meningkatkan berbagai biaya operasi perusahaan, menyebabkan harga jual barang meningkat dan menurunkan daya beli masyarakat. Hal ini berdampak pada turunnya penjualan perusahaan, 
sehingga keuntungan dan kinerja keuangan perusahaan mengalami penurunan.

Tidak stabilnya kondisi ekonomi makro akan berdampak buruk pada kinerja keuangan perusahaan secara umum. Rendahnya kinerja keuangan yang tercermin dalam laporan keuangan membuat para investor mengurangi jumlah permintaan atas saham perusahaan tersebut. Menurunnya jumlah permintaan saham akan mengakibatkan harga saham ikut turun dan hal ini menunjukkan nilai perusahaan yang rendah. Pareira (2010) membuktikan bahwa terdapat hubungan negatif antara inflasi dengan harga saham. Triayuningsih (2003) menyebutkan bahwa laju inflasi tidak memiliki pengaruh yang signifikan terhadap return saham yang berdampak pada harga saham perusahaan manufaktur. Harga saham justru lebih terpengaruh oleh tren dari tingkat suku bunga selama periode tersebut, di mana suku bunga berpengaruh negatif dan signifikan terhadap harga saham.

Secara umum, pasar modal merupakan tempat kegiatan perusahaan mencari dana untuk membiayai kegiatan usahanya. Selain itu, pasar modal juga merupakan suatu usaha penghimpunan dana masyarakat secara langsung dengan cara menanamkan dana ke dalam perusahaan yang sehat dan baik pengelolaannya. Fungsi utama pasar modal adalah sebagai sarana pembentukan modal dan akumulasi dana bagi pembiayaan suatu perusahaan atau emiten. Pasar modal merupakan salah satu alternatif pilihan investasi yang dapat menghasilkan tingkat keuntungan optimal bagi investor.

Investasi dapat diartikan sebagai suatu kegiatan menempatkan dana pada satu atau lebih dari satu aset selama periode tertentu dengan harapan dapat memperoleh penghasilan dan atau peningkatan nilai investasi (Suad Husnan,1998). Investasi pada saham dianggap mempunyai tingkat resiko yang lebih besar dibandingkan dengan alternatif investasi lain, seperti obligasi, deposito, dan tabungan. Setiap investor di pasar saham sangat membutuhkan informasi yang relevan dengan perkembangan transaksi di bursa, hal ini sangat penting untuk dijadikan bahan pertimbangan dalam menyusun strategi dan pengembalian keputusan investasi di pasar modal. Dengan adanya pasar modal diharapkan dapat membantu industri perbankan untuk bertahan dalam perekonomian Indonesia yang selalu berfluktuasi.

QE Journal | Vol.06 - No. 01 Maret 2017 - 73 
Berdasarkan uraian diatas, permasalahan yang akan diteliti adalah bagaimana pengaruh dari Total Asset, Laba Bersih (Net Revenue), Inflasi, dan BI Rate terhadap Harga Saham pada perusahaan Manufaktur yang tercatat di BEI tahun 2005-2014?. Sehingga terdapat tujuan dalam penelitian ini adalah untuk menganalisis pengaruh Total Asset, Laba Bersih (Net Revenue), Inflasi, dan BI Rate terhadap Harga Saham terhadap Harga Saham pada perusahaan Manufaktur yang tercatat di BEI tahun 2005-2014.

Menurut Fred dan Copeland (1999:166) saham merupakan tanda penyertaan atau kepemilikan seseorang atau badan dalam suatu perusahaan, selembar saham adalah selembar kertas yang menerangkan bahwa pemilik kertas tersebut adalah pemiliknya (berapapun porsinya atau jumlahnya) dari suatu perusahaan yang menerbitkan kertas (saham) tersebut. Selembar saham mempunyai nilai atau harga. Harga saham dapat dibedakan menjadi 3 (tiga), yaitu: (a) Harga Nominal ; Harga yang tercantum dalam sertifikat saham yang ditetapkan oleh emiten untuk menilai setiap lembar saham yang dikeluarkan. Besarnya harga nominal memberikan arti penting saham karena deviden minimal biasanya ditetapkan berdasarkan nilai nominal. (b) Harga Perdana ; Harga ini merupakan harga pada waktu harga saham tersebut dicatat di bursa efek. Harga saham pada pasar perdana biasanya ditetapkan oleh penjamnin emisi (underwriter) dan emiten. Dengan demikian akan diketahui berapa harga saham emiten itu akan dijual kepada masyarakat biasanya untuk menentukan harga perdana. (c) Harga Pasar ; Kalau harga perdana merupakan harga jual dari perjanjian emisi kepada investor, maka harga pasar adalah harga jual dari investor yang satu dengan investor yang lain. Harga ini terjadi setelah saham tercatat di bursa. Transaksi di sini tidak lagi melibatkan emiten dari penjamin emisi harga ini yang disebut sebagai harga di pasar sekunder dan harga inilah yang benar-benar mewakili harga perusahaan penerbitnya, karena pada transaksi di pasar sekunder, kecil sekali terjadi negosiasi harga investor dengan perusahaan penerbit. Harga yang setiap hari diumumkan di surat kabar atau media lain adalah harga pasar.

Dalam teori ekonomi juga dikenal adanya istilah laba, akan tetapi pengertian laba di dalam teori ekonomi berbeda dengan pengertian laba menurut akuntansi. Dalam teori ekonomi, para ekonom mengartikan laba sebagai suatu kenaikan dalam kekayaan perusahaan, sedangkan dalam 
akuntansi, laba adalah perbedaan pendapatan yang direalisasi dari transaksi yang terjadi pada waktu dibandingkan dengan biaya-biaya yang dikeluarkan pada periode tertentu. ( http://kelompoklaba.wordpress.com ).

Total Assets Turnover merupakan rasio yang menunjukkan tingkat efisiensi penggunaan keseluruhan aktiva perusahaan dalam menghasilkan volume penjualan tertentu. Rasio ini yang menunjukkan perputaran aktiva diukur dari volume penjualan. Jadi semakin besar rasio ini semakin baik yang berarti bahwa aktiva dapat lebih cepat berputar dan meraih laba dan menunjukkan semakin efisien penggunaan keseluruhan aktiva dalam menghasilkan penjualan.

Dengan kata lain jumlah aset yang sama juga dapat memperbesar volume penjualan apabila assets turnovernya ditingkatkan atau diperbesar. Total Assets Turnover ini penting bagi para kreditur dan pemilik perusahaan, tapi akan lebih penting lagi bagi manajemen perusahaan, karena hal ini akan menunjukkan efisien tidaknya penggunaan seluruh aktiva dalam perusahaan. Semakin besar TAT akan semakin baik, karena semakin efisien seluruh aktiva yang digunakan dalam menunjang kegiatan (Ang, 1997) peningkatan ROE dipengaruhi oleh TAT di indikasikan bahwa semakin efektif perputaran aset perusahaan akan meningkatkan laba perusahaan. Meningkatnya laba akan meningkatkan perubahan ROE, (Brigham, 2001).

BI Rate berfungsi sebagai sinyal dari kebijakan moneter Bank Indonesia, dengan demikian dapat diambil kesimpulan bahwa respon kebijakan moneter dinyatakan dalam kenaikan, penurunan, atau tidak berubahnya BI Rate tersebut. Inflasi adalah kecenderungan dari harga-harga untuk naik secara umum dan terus menerus Sukirno (2002). Akan tetapi bila kenaikan harga hanya dari satu atau dua barang saja tidak disebut inflasi, kecuali bila kenaikan tersebut meluas atau menyebabkan kenaikan sebagian besar dari harga barang-barang lain (Boediono,2000).

Kenaikan harga-harga barang itu tidaklah harus dengan persentase yang sama.Inflasi merupakan kenaikan harga secara terus-menerus dan kenaikan harga yang terjadi pada seluruh kelompok barang dan jasa (Pohan, 2008). Bahkan mungkin dapat terjadi kenaikan tersebut tidak bersamaan. Yang penting kenaikan harga umum barang secara terusmenerus selama suatu periode tertentu. Kenaikan harga barang yang terjadi hanya sekali saja, meskipun dalam persentase yang cukup besar dan 
terus-menerus, bukanlah merupakan inflasi (Nopirin, 2000). Kenaikan sejumlah bentuk barang yang hanya sementara dan sporadis tidak dapat dikatakan akan menyebabkan inflasi. Tingkat inflasi antara negara yang satu dengan yang lainnya berbeda-beda, seperti inflasi di Indonesia dalam keadaan normal biasanya di bawah $10 \%$ per tahun. Tetapi tingkat itu dapat berubah-ubah, seperti ketika terjadi krisis ekonomi di Indonesia, tingkat inflasi mencapai kurang lebih $80 \%$.

\section{METODE PENELITIAN}

Pengambilan dan pengumpulan data yang akan digunakan dalam penelitian ini akan dilakukan di yahoo finance, IDX, dan BI. Penelitian ini akan dilakukan dari tahun 2005 sampai tahun 2014. Dalam rangka pengumpulan data penulis menggunakan metode riset pustaka yaitu metode penelitian yang digunakan untuk mendapatkan informasi yang dibutuhkan dengan cara mempelajari buku-buku, internet atau literaturyang behubungan dengan permasalahan yang akan dibahas dalam penelitian ini.

Data yang digunakan pada penelitian ini adalah data sekunder berupa data variabel-variabel ekonomi seperti tingkat inflasi, tingkat suku bunga SBI, total assets, net revenues, BI rate Indonesia terhadap perusahaan manufaktur yang tercantum dalam BEI, berupa data tahunan dari tahun (2005-2014) yang diperoleh pada situs www.bi.go.id, www.idx.com, dan www.yahoo.finance.com.

Langkah-langkah analisis dalam penelitian ini meliputi: (a) Pemilihan perusahaan manufaktur berdasarkan tahun tertua didirikannya, (b) Data saham diambil dari tahun 2005-2014. Ketiga saham tersebut adalah Intan Wijaya Internasional (INCI), Indocoment Tunggal Prakasa (INTP), Charoen Pokphand Indonesia (CPIN), (c) Uji analisis regresi data panel

Data skunder dikumpulkan dari dokumen-dokumen yang ada dan melalui media online yang mendukung penelitian ini. Dalam rangka pengumpul-an data penulis menggunakan metode riset pustaka yaitu metode penelitian yang digunakan untuk men-dapatkan informasi yang dibutuhkan dengan cara mempelajari buku-buku atau literatur yang ber-hubungan dengan permasalahan yang akan dibahas dalam penelitian ini.Penelitian ini menggunakan 3 perusahaan manufaktur sebagai sempel yang meliputi Intan Wijaya Internasional (INCI), Indocoment Tunggal Prakasa (INTP), 
Charoen Pokphand Indonesia (CPIN), dalam menentukan perusahaan manufaktur dilihat dari tahun terlama didirikan perusahaannya dan semua data diambil dari tahun 2005 sampai dengan tahun 2014.

Variabel-variabel dalam penelitian ini merupakan faktor-faktor yang dianggap mempengaruhi return saham perusahaan manufaktur. Analisis yang akan digunakan adalah analisis regresi data panel karena data yang dianalisis berupa datapooled (gabungan antara data crossection/perusahaan dengan data time series/tahun).

Koefisien determinasi $\left(\mathrm{R}^{2}\right)$, digunakan untuk mengukur seberapa besar variabel-variabel bebas dapat menjelaskan variabel terikat. Koefisien ini menunjukkan seberapa besar variasi total pada variabel terikat yang dapat dijelaskan oleh variabel bebasnya dalam model regresi tersebut. Nilai dari koefisien determinasi ialah 0 hingga 1 . Nilai $R^{2}$ yang mendekati 1 menunjukkan bahwa variabel dalam model tersebut dapat mewakili permasalahan yang diteliti, karena dapat menjelaskan variasi yang terjadi pada variabel dependennya. Nilai koefisien determinasi akan cenderung semakin besar bila jumlah variabel bebas dan jumlah data yang diobservasi semakin banyak. Oleh karena itu, digunakan ukuran adjusted $R^{2}\left(R^{2}\right)$, untuk menghilangkan bias akibat adanya penambahan jumlah variabel bebas dan jumlah data yang diobservasi. Dapat diestimasi nilai Adjusted $\mathrm{R}^{2}=$ 0.856006 menandakan bahwa variasi dari perubahan Harga Saham (Y) mampu dijelaskan secara serentak oleh variabel-variabel Net Revenue (X1), Total Assets (X2), Inflasi (X3)sebesar 85,60\%, sedangkan sisanya sebesar $14,4 \%$ dijelaskan oleh faktor-faktor lain yang tidak masuk dalam model.

Uji spesifikasi model yang pertama dilakukan dengan menggunakan Uji Chow (Chow Test) untuk menguji apakah lebih baik menggunakan common effect atau fixed effects. Dengan total data sebanyak 30, berikut adalah tabel hasil uji Chow Test dari regresi data panel:

Dari uji chow test dibawah, dapat dilihat bahwa nilai probabilitas chisquarenya lebih besar dari $\alpha(0,000<0,05)$ sehingga H0 ditolak dan H1 diterima, model yang paling tepat untuk digunakan adalah Fixed Effect Model (FEM). Uji spesifikasi model tidak terhenti pada chow test yang menyimpulkan bahwa fixed effect lebih baik. 
Tabel 1. Data Harga Saham, Total Asset, Laba Bersih (Net Revenue), Inflasi, BI Rate di Perusahaan Manufaktur Tahun 2005-2014

\begin{tabular}{|c|c|c|c|c|c|c|}
\hline $\begin{array}{l}\text { Nama } \\
\text { Perusahaan }\end{array}$ & Tahun & $\begin{array}{l}\text { Harga } \\
\text { Saham }\end{array}$ & $\begin{array}{l}\text { Total } \\
\text { Assets }\end{array}$ & $\begin{array}{l}\text { Net } \\
\text { Revenue }\end{array}$ & Inflasi & BI Rate \\
\hline INCI & 2005 & 365.00 & 179.2 & 157.2 & $\begin{array}{l}104.02 \\
5\end{array}$ & 12.75 \\
\hline INCI & 2006 & 245.00 & 172.8 & 116.7 & 13.331 & 9.75 \\
\hline INCI & 2007 & 280.00 & 179.8 & 121.7 & 6.404 & 8.00 \\
\hline INCI & 2008 & 88.00 & 175.4 & 136.2 & 10.308 & 9.25 \\
\hline INCI & 2009 & 196.00 & 157.6 & 69.8 & 4.895 & 7.146 \\
\hline INCI & 2010 & 245.00 & 134.0 & 48.5 & 5.125 & 6.5 \\
\hline INCI & 2011 & 210.00 & 125.2 & 50.3 & 5.38 & 6.58 \\
\hline INCI & 2012 & 245.00 & 132.3 & 64.7 & 4.27 & 5.77 \\
\hline INCI & 2013 & 240.00 & 136.2 & 81.3 & 6.96 & 6.48 \\
\hline INCI & 2014 & 238.00 & 147.9 & 110 & 6.41 & 7.53 \\
\hline INTP & 2005 & 3.550 & 10.536 & 5.592 & $\begin{array}{l}104.02 \\
5\end{array}$ & 12.75 \\
\hline INTP & 2006 & 5.750 & 9.598 & 6.325 & 13.331 & 9.75 \\
\hline INTP & 2007 & 8.200 & 10.038 & 7.324 & 6.404 & 8.00 \\
\hline INTP & 2008 & 4.600 & 11.287 & 9.780 & 10.308 & 9.25 \\
\hline INTP & 2009 & 13.700 & 13.277 & 10.576 & 4.895 & 7.146 \\
\hline INTP & 2010 & 15.950 & 15.346 & 11.138 & 5.125 & 6.5 \\
\hline INTP & 2011 & 17.050 & 18.151 & 13.888 & 5.38 & 6.58 \\
\hline INTP & 2012 & 22.650 & 22.755 & 17.290 & 4.27 & 5.77 \\
\hline INTP & 2013 & 20.000 & 26.607 & 18.691 & 6.96 & 6.48 \\
\hline INTP & 2014 & 25.000 & 28.885 & 19.996 & 6.41 & 7.53 \\
\hline CPIN & 2005 & 5.543 & 2.621 & 5.541 & $\begin{array}{l}104.02 \\
5\end{array}$ & 12.75 \\
\hline CPIN & 2006 & 6.667 & 3.162 & 6.662 & 13.331 & 9.75 \\
\hline CPIN & 2007 & 1.060 & 4.761 & 8.680 & 6.404 & 8.00 \\
\hline CPIN & 2008 & 435.00 & 5.179 & 13.312 & 10.308 & 9.25 \\
\hline CPIN & 2009 & 2.250 & 5.450 & 14.570 & 4.895 & 7.146 \\
\hline CPIN & 2010 & 1.840 & 6.519 & 15.078 & 5.125 & 6.5 \\
\hline CPIN & 2011 & 2.050 & 8.849 & 21.311 & 5.38 & 6.58 \\
\hline CPIN & 2012 & 3.500 & 12.349 & 21.311 & 4.27 & 5.77 \\
\hline CPIN & 2013 & 3.400 & 15.723 & 25.663 & 6.96 & 6.48 \\
\hline CPIN & 2014 & 3.780 & 20.863 & 29.151 & 6.41 & 7.53 \\
\hline
\end{tabular}

Sumber: Data diolah, 2016

QE Journal | Vol.06 - No. 01 Maret 2017 - 78 
Tabel 2. Hasil Uji Chow Test

Redundant Fixed Effects Tests

Pool: AKU

Test cross-section fixed effects

Effects Test

Statistic

d.f.

Prob.

Cross-section F

0.168227

$(2,9)$

0.8478

Cross-section Chi-square

0.587231

2

0.7456

Cross-section fixed effects test equation:

Dependent Variable: Y?

Method: Panel Least Squares

Date: 01/05/16 Time: 14:50

Sample: 20052014

Included observations: 9

Cross-sections included: 3

Total pool (unbalanced) observations: 16

$\begin{array}{lllll}\text { Variable } & \text { Coefficient } & \text { Std. Error } & \text { t-Statistic } & \text { Prob. } \\ \text { C } & 1191.102 & 1733.917 & 0.686943 & 0.5063 \\ \text { TOTAL_ASSET? } & 1.076184 & 0.176497 & 6.097452 & 0.0001 \\ \text { NET_REVENUE? } & -0.508712 & 0.147059 & -3.459243 & 0.0053 \\ \text { INFLASI? } & -0.035591 & 0.026208 & -1.358018 & 0.2017 \\ \text { BI_RATE? } & 0.261084 & 0.289232 & 0.902681 & 0.3860 \\ & & & & \\ \text { R-squared } & 0.787528 & \text { Mean dependent var } & 5003.063 \\ \text { Adjusted R-squared } & 0.710265 & \text { S.D. dependent var } & 5737.232 \\ \text { S.E. of regression } & 3088.181 & \text { Akaike info criterion } & 19.15886 \\ \text { Sum squared resid } & 1.05 E+08 & \text { Schwarz criterion } & 19.40029 \\ \text { Log likelihood } & -148.2709 & \text { Hannan-Quinn criter. } & 19.17122 \\ \text { F-statistic } & 10.19287 & \text { Durbin-Watson stat } & 0.774645 \\ \text { Prob(F-statistic) } & 0.001064 & & \end{array}$

Pendekatan metode kuadrat terkecil biasa adalah asumsi intercept dan slope dari persamaan regresi (model yang dianggap konstan baik antar negara maupun antar waktu (all coeffixients constant across time and individuals). Satu cara untuk memperhatikan unit cross-section atau unit time series dengan memasukkan variabel dummy untuk mengijinkan terjadinya 
perbedaan nilai parameter yang berbeda-beda, baik lintas unit cross-section maupun antar unit waktu.

Tabel 3. Hasil Uji Fixed

Dependent Variable: Y?

Method: Pooled Least Squares

Date: 01/05/16 Time: 14:50

Sample: 20052014

Included observations: 9

Cross-sections included: 3

Total pool (unbalanced) observations: 16

$\begin{array}{lllll}\text { Variable } & \text { Coefficient } & \text { Std. Error } & \text { t-Statistic } & \text { Prob. } \\ \text { C } & 2007.861 & 2971.702 & 0.675660 & 0.5162 \\ \text { TOTAL_ASSET? } & 0.939288 & 0.754060 & 1.245640 & 0.2443 \\ \text { NET_REVENUE? } & -0.471733 & 0.778950 & -0.605602 & 0.5597 \\ \text { INFLASI? } & -0.036066 & 0.029422 & -1.225813 & 0.2514 \\ \text { BI_RATE? } & 0.251263 & 0.314604 & 0.798665 & 0.4450 \\ \text { Fixed Effects (Cross) } & & & & \\ \text {-INCI--C } & -1260.804 & & & \\ \text { _INTP--C } & 820.2463 & & & \\ \text { _CPIN--C } & -139.7015 & & & \end{array}$

Effects Specification

Cross-section fixed (dummy variables)

$\begin{array}{llll}\text { R-squared } & 0.795185 & \text { Mean dependent var } & 5003.063 \\ \text { Adjusted R-squared } & 0.658641 & \text { S.D. dependent var } & 5737.232 \\ \text { S.E. of regression } & 3352.032 & \text { Akaike info criterion } & 19.37216 \\ \text { Sum squared resid } & 1.01 \mathrm{E}+08 & \text { Schwarz criterion } & 19.71016 \\ \text { Log likelihood } & -147.9773 & \text { Hannan-Quinn criter. } & 19.38947 \\ \text { F-statistic } & 5.823665 & \text { Durbin-Watson stat } & 0.851308 \\ \text { Prob(F-statistic) } & 0.009878 & & \end{array}$

Pendekatan yang sering dilakukan adalah dengan mengizinkan intercep bervariasi antar unit cross-section. Untuk melakukan evaluasi dan interpretasi untuk mengetahui seberapa baik hasil regresi yang didapatkan. Karena metode yang terpilih dalam penelitian ini adalah 
metode random effect maka pengujian hipotesis dilakukan berdasarkan nilai dari hasil regresi pada metode random effect.

Tabel 4. Hasil Uji PLS

Dependent Variable: Y?

Method: Pooled Least Squares

Date: 01/05/16 Time: 14:50

Sample: 20052014

Included observations: 9

Cross-sections included: 3

Total pool (unbalanced) observations: 16

$\begin{array}{lllcc}\text { Variable } & \text { Coefficient } & \text { Std. Error } & \text { t-Statistic } & \text { Prob. } \\ \text { TOTAL_ASSET? } & 1.113300 & 0.164284 & \mathbf{6 . 7 7 6 6 6 4} & \mathbf{0 . 0 0 0 0} \\ \text { NET_REVENUE? } & -0.473710 & 0.134880 & \mathbf{- 3 . 5 1 2 0 9 3} & \mathbf{0 . 0 0 4 3} \\ \text { INFLASI? } & -0.025587 & 0.021304 & \mathbf{- 1 . 2 0 1 0 1 4} & \mathbf{0 . 2 5 2 9} \\ \text { BI_RATE? } & 0.347232 & 0.254830 & \mathbf{1 . 3 6 2 6 0 2} & \mathbf{0 . 1 9 8 0} \\ & & & \\ \text { R-squared } & 0.778413 & \text { Mean dependent var } & 5003.063 \\ \text { Adjusted R-squared } & 0.723016 & \text { S.D. dependent var } & 5737.232 \\ \text { S.E. of regression } & 3019.463 & \text { Akaike info criterion } & 19.07586 \\ \text { Sum squared resid } & 1.09 \mathrm{E}+08 & \text { Schwarz criterion } & 19.26901 \\ \text { Log likelihood } & -148.6069 & \text { Hannan-Quinn criter. } & 19.08575 \\ \text { Durbin-Watson stat } & 0.774452 & & \end{array}$

Berdasarkan hasil diatas disimpulkan:

a. Total Asset memiliki nilai t-hitung $<\alpha=5 \%$, memiliki pengaruh positif sehingga signifikan terhadap harga saham.

b. Laba Bersih (Net Revenue) memiliki nilai t-hitung $>\alpha=5 \%$, dapat dinyatakan bahwa tidak berpengarunh positif.

c. Inflasi memiliki nilai t-hitung $>\alpha=5 \%$, dapat dinyatakan tidak berpengaruh positif.

d. BI Rate mempunyai pengaruh positif sehingga signifikan terhadap harga saham.

Uji distribusi normal adalah uji untuk mengukur apakah data memiliki distribusi normal sehingga dapat dipakai dalam statistik parametrik (statistik inferensial). Pendugaan persamaan dengan menggunakan metode QE Journal | Vol.06 - No. 01 Maret 2017 - 81 
OLS harus memenuhi sifat kenormalan, karena jika tidak normal dapat menyebabkan varians infinitif (ragam tidak hingga atau ragam yang sangat besar). Hasil pendugaan yang memiliki varians infinitif menyebabkan pendugaan dengan metode OLS akan menghasilkan nilai dugaan yang not meaningful (tidak berarti). Salah satu metode yang banyak digunakan untuk menguji Normalitas adalah Jarque-Bera test.

Pengujian normalitas dilakukan dengan Jarque-Bera test. Jarque-Bera test mempunyai distribusi chi square dengan derajat bebas dua. Jika hasil Jarque-Bera test lebih besar dari nilai chi square pada $\alpha=5$ persen, maka tolak hipotesis nul yang berarti tidak berdistribusi normal. Jika hasil Jarque-Best test lebih kesil dari nilai chi square pada $\alpha=5$ persen, maka terima hipotesis nul yang berarti error term berdistribusi normal.

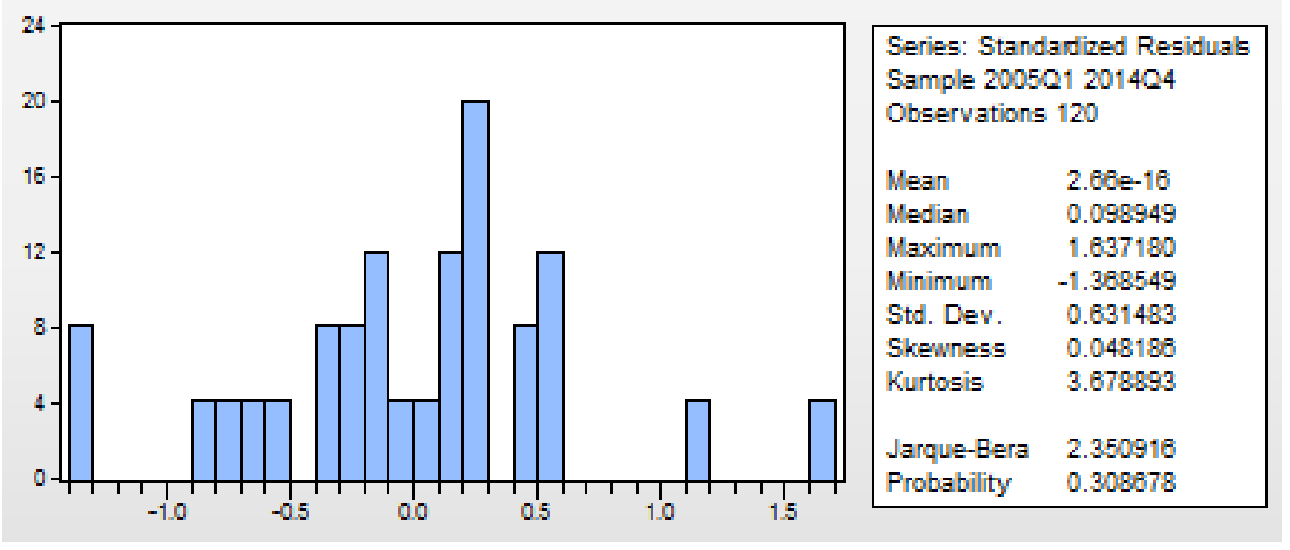

Gambar 1. Hasil Uji Normalitas

Untuk mendeteksi apakah residualnya berdistribusi normal atau tidak dengan membandingkan nilai Jarque Bera (JB) dapat diketahui juga dari tingkat probalbility sebesar 0,308678 $(p>5 \%)$ maka dapat disimpulkan bahwa residual berdistribusi normal.

\section{SIMPULAN DAN SARAN}

\section{Simpulan}

Hasil pengujian hipotesis dengan menggunakan model regresi data panel dengan empat variabel independen (Laba Bersih (Net Revenue), Total Asset, Inflasi, BI Rate) dan satu variabel dependen yaitu (Harga Saham) menunjukkan hasil sebagai berikut: 
Variabel Laba Bersih (Net Revenue), Total Asset, Inflasi, tidak memiliki pengaruh signifikan terhadap tingkat harga saham pada perusahaan manufaktur yang tercatat di BEI. Variabel BI Rate memiliki pengaruh yang signifikan terhadap tingkat Harga Saham pada perusahaan manufaktur yang tercatat di BEI.

\section{Saran}

Saran yang dapat diberikan dari penelitian ini adalah sebagai berikut: Penelitian selanjutnya dapat menambah beberapa variabel lain yang mempengaruhi harga saham sebuah perusahaan manufaktur. Pada penelitian yang telah dilakukan, terdapat banyak variabel independennya yang berkaitan dengan faktor internal, maka penulis menyarankan untuk penelitian selanjutnya lebih menggunakan variabel tingkat inflasi serta suku bunga (BI Rate).

\section{DAFTAR PUSTAKA}

Ang, Robert. 1997. Buku Pintar Pasar Modal Indonesia, Mediasoft Indonesia, Jakarta.

Brigham, F., dan J. Houstan. 2001. Manajemen Keuangan, Edisi Kedelapan, Erlangga, Jakarta.

Boediono. 2001. “Ekonomi Moneter.” BPFE. Yogyakarta.

Dahlan Siamat. 2005. Manajemen Lembaga Keuangan, FE UI, Jakarta.

Fred, Weston, J. dan Thomas E. Copeland. 1999. Manajemen Keuangan. Edisi 8. Jakarta: Bina Rupa Aksara.

Fabozzi, F.J. 1999. Manajemen Investasi. Salemba Empat. Jakarta.

Harahap, Sofyan, 2001. Sistem Pengawasan Manajemen, Penerbit Quantum, Jakarta

Hermuningsih, Sri dan Dewi Kusuma Wardani. 2009. Faktor-Faktor Yang Mempengaruhi Nilai Perusahaan Pada Perusahaan Yang Terdaftar Di Bursa Efek Malaysia Dan Bursa Efek Indonesia. Jurnal Siasat Bisnis. 13(2): h: 173-183.

http://kelompoklaba.wordpress.com 
Jogiyanto. 2008. Metode Penilitian Sistem Informasi, Jogjakarta: Andi Publisher.

Nopirin. 2000. Ekonomi Moneter. Buku II. Edisi ke 1. Cetakan Kesepuluh. BPFE UGM.Yogyakarta.

Pareira, Diego, 2010, “Inflation, Real Stock Prices and Earnings : Friedman was Right". Garmendia.

Pohan, Aulia, 2008. Kerangka Kebijakan Moneter dan Implikasinya di Indonesia, Raja Grafindo Persada, Jakarta.

Sadono Sukirno, 2002. Teori Mikro Ekonomi. Cetakan Keempat Belas. Rajawali Press: Jakarta

Suad Husnan , 1998, Dasar- dasar Teori portofolio dan Analisis Sekuritas, Edisi Ketiga, UPP AMP YKPN, Yogyakarta

Suharli, Michell. 2005. Studi Empiris Terhadap Dua Faktor Yang Mempengaruhi Return Saham Pada Industri Food \& Beverages Di Bursa Efek Jakarta. Jurnal Akuntansi dan Keuangan, 7(2): h: 99- 116

Triayuningsih, Retno, 2003, “Analisis Pengaruh Kinerja Keuangan

Perusahaan dan Faktor Ekonomi Makro terhadap Return Saham Perusahaan Industri Manufaktur di BEJ Periode 1999-2001", Tesis, Program Magister Manajemen Universitas Diponogoro 